\title{
Teacher Disempowerment in the Education System of Ecuador
}

\author{
Tammy M Fajardo-Dack ${ }^{1, *}$ \\ ${ }^{1}$ Languages and Literacies Education and Comparative, International, and Development Education, OISE - \\ University of Toronto, Toronto, Canada \\ *Correspondence: Languages and Literacies Education and Comparative, International, and Development Education, \\ OISE - University of Toronto, 252 Bloor Street West, 10-253, Toronto, ON M5S 1V6, Canada. E-mail: \\ tammy.fajardodack@mail.utoronto.ca
}

Received: April 19, 2016

doi:10.5430/wje.v6n3p82
Accepted: June 3, 2016 Online Published: June 13, 2016

URL: http://dx.doi.org/10.5430/wje.v6n3p82

\begin{abstract}
A profound and systemic education change requires taking into consideration the several factors that intervene, particularly, and most importantly, the role of the teacher. Ecuador, since 2009 has been immersed in constant changes to achieve an educational transformation; however, nothing has been invested in the professional development of teachers, instead, all efforts and funds have been assigned to create more directions for teachers to follow. This article paper focuses on the role of teachers in the education system in Ecuador. It reviews the objectives of revalorizing the teaching profession within the literature of teacher empowerment with the purpose of critically analyze if what is written in official documents is what is happening in reality in the country. Moreover, it examines the role of Ecuadorian teachers in terms of the factors that have led to their disempowerment: feminization, technologization, deskilling, intensification, and privatization.
\end{abstract}

Keywords: empowerment, disempowerment, teachers, education system, Ecuador

\section{Introduction}

The latest education system in Ecuador started its implementation in 2009 with a new program proposed by the Ministry of Education (MOE). It is an ambitious plan with twenty-one specific objectives and a series of radical changes that had to be accomplished by 2015. The objectives cover all areas involved: infrastructure, technology, and teachers, in this specific order.

After seven years under the so-called 'educational revolution' (proclaimed like this by the government and its political party) there is no significant evidence of a fruitful change. Although the public investment in education has increased - more buildings, technology, textbooks, materials, etc. - less attention has been given to the initial and continuous training of teachers, which setbacks the development of students' learning skills and competencies. It seems that there is a mismatch between the written documents, praised internationally as models to follow, and the stories told by teachers about their role in the classroom and in the school.

This article presents the actions taken by the MOE in Ecuador to meet the objectives for revalorizing the teaching profession of the country. This introduction is followed by a thorough description of the education system in the country according to the government. Next, the teachers' role in the education system is analyzed within the literature of teacher empowerment and the factors that have led to their disempowerment to critically analyze if what is written in official documents is what is happening in reality in the country. The paper ends with suggestions about the possible solutions for teachers to regain power and demonstrate to the government that they are the agents of the profound transformation pursued.

\section{Education in Ecuador}

Ecuador has gone through a political and institutional transformation process since its new Constitution was established in 2008 and the National Plan for Good Living was passed in 2009. According to the Plan developers, it is the result of the search for new ways of living of Latin American social actors. Its purpose is to confront the neoliberal economic model and to promote an alternative to development in which inclusiveness, sustainability and 
democracy are the goals.

According to Ramirez (2008), former National Secretary for Planning and Development of Ecuador and now National Secretary of Higher Education, Science, Technology and Innovation, Good Living is a complex, non-linear concept in permanent re-signification that could be defined as:

Covering needs, achieving a dignified quality of life and death; loving and being loved; the healthy flourishing of all individuals in peace and harmony with nature; and achieving an indefinite reproduction perpetuation of human cultures. Good Living implies having free time for contemplation and personal emancipation; enabling the expansion and flourishing of people's liberties, opportunities, capabilities and potentialities so as to simultaneously allow society, specific territories, different collective identities, and each individual, understood both in universal and relative terms, to achieve their objectives in life (without causing any kind of material or subjective dominance over any other individual). Our concept of Good Living compels us to re-build the public sphere in order to recognize, understand and value ourselves as diverse but equal individuals, and in order to advance reciprocity and mutual recognition, enable self-development, and build a shared social future. (p. 387)

Since the constitutionalization of this plan, institutions, new and old systems, programs, and projects must be designed or re-designed in accordance to the objectives of 'Good Living' with the purpose of achieving the five revolutions proposed by the government: a constitutional and democratic revolution; an ethical revolution; an economic, productive, and agrarian revolution; a social revolution; and a revolution in defense of Latin American dignity, sovereignty, and integration (Ramírez, 2013).

Within this systemic transformation, special attention has been given to the redefinition of the role of education, as it is seen as an essential component of 'Good Living,' because it allows the development of human potential and ensures equal access to opportunities to all people. In the same way, Good Living is defined as a fundamental axis of education to the extent that the "educational process should seek to prepare future citizens for a society that is democratic, equitable, inclusive, and peaceful; a society that promotes interculturality, tolerates diversity, and respects nature - all principles of Good Living” (Ministerio de Educación del Ecuador, 2012).

The main objective of the National Program of Education for Democracy and Good Living developed by the Ministry of Education (MOE) is to transform the old system characterized by the mere transmission of knowledge into an education system that promotes creativity, critical thinking, and the production of knowledge which, according to the concepts of 'knowledge society' and 'knowledge economy,' is a commodity to be traded for economic development, or, in the words of the Ecuadorian government, to achieve an economic and social revolution.

The MOE identified the reasons for the failure of past education models in the country and developed a program with clear objectives to assure a new scenario for education. These objectives were proposed as twenty "ruptures with the status quo in education" (Ministerio de Educación del Ecuador, 2012) and were classified into four major groups each containing several specific aims. (Van Damme, Aguerrondo, Crespo Burgos, \& Robalino Campos, 2013).

a. Contributions to the re-conceptualization of education as a right of individuals and communities

In this group, seven specific aims are considered necessary to establish the right to education to all individuals in Ecuador. These ruptures seek to guarantee education, assigning enough economic resources, as a public free and secular service. They promote the active participation of parents and families as important elements of the educational process. In addition, they address private and co-funded schools in terms of their rights' protection. One of the most important elements of this rupture is the prohibition to suspend educational activities, issue that seemed to be a mandatory activity in every school year in the past. (Van Damme, Aguerrondo, Crespo Burgos, \& Robalino Campos, 2013).

b. A profound change in the structure of the national education system

This rupture includes four objectives, being the most important the reinstating of the State on the education system of the country as the manager of a new educational model that encourages citizens to participate in decision-making processes, as well as in monitoring and accountability processes.

The most profound change proposed with this rupture is the strengthening of intercultural bilingual education to ensure linguistically and culturally relevant education for the several indigenous nationalities of the country. (Van Damme, Aguerrondo, Crespo Burgos, \& Robalino Campos, 2013). 
c. Strive to transcend the old paradigm of quality education and equal opportunities, to guarantee better learning for students

This group of five objectives aims to put into practice the overused rhetoric about improving quality of education by introducing significant changes to traditional practices, and by encouraging all participants of the educational system to become agents of social change. Achieving this objective means overcoming racism, discrimination and exclusion. (Van Damme, Aguerrondo, Crespo Burgos, \& Robalino Campos, 2013).

\section{d. Revalorization of the teaching profession}

The four objectives of this rupture were developed with the purpose of reviving the teaching profession, giving it the importance it has within any educational system. They state that only the best teachers, who will be selected through rigorous and transparent processes that consider merits and competences, will be hired. Similarly, salaries will be assigned according to a meritocratic scale that ensures fair and decent pay.

A National University of Education (UNAE by its name in Spanish) that contributes to the initial training of teachers, who will meet the requirements before mentioned, is also an objective of this group. (Van Damme, Aguerrondo, Crespo Burgos, \& Robalino Campos, 2013).

Anyone who reads the MOE's program would think that although it is very ambitious, it is the ideal path to give a complete makeover to the 'precarious and obsolete' programs of the past. In fact, the plan has raised the attention of several Latin American countries which have invited the representatives of the MOE to share their stories of success. Unfortunately, these are no other than "sacred stories", which according to Crites are a "theory-driven view of practice shared by practitioners, policy makers, and theoreticians" (as cited in Clandinin \& Conelly, 1996, p. 25), created without social participation and behind teachers' backs. This traditional type of educational reform - vertical, technocrat, and expert - has failed around the world and now is failing in Ecuador. Teachers' "secret and cover stories" lived in the classroom and shared with other teachers in secret places to avoid problems (Clandinin \& Conelly, 1996) are very different from what is written on papers and said by MOE bureaucrats in meetings, conferences, and speeches; it seems teachers and officials are living in two different countries.

After six years under the so-called 'educational revolution' (embedded in the economic and social revolutions of the government) there is no tangible proof of the proclaimed transformation. Some changes are seen, indeed, but not evidenced in the training of teachers, improvement of students' performance, or in the implementation of curriculum, but instead in the overspending for the construction and implementation of new schools.

\subsection{Schools of the Millennium}

The schools of the millennium (SOM) are one of the most important projects of the government politics to improve public education. SOMs are built to guarantee access to education in rural areas. Little schools that served specific communities have been closed and students relocated in SOMs that are usually far from their homes.

Currently there are 59 SOMs functioning and a plan to build 212 more. According to the MOE each school costs approximately 2 million dollars; they have classrooms equipped with digital whiteboards, kitchens, eating areas, recreational spaces, science labs, virtual libraries, and computer labs with broad band internet. It sounds like a dream come true to have such a wonderful site for learning; nevertheless, these resources are underutilized due to the lack of teacher training and sometimes even the lack of enough teachers. Rosa Maria Torres, a recognized Ecuadorian pedagogue, linguist, and social activist shares her experience when visiting the third SOM a few weeks after the opening.

When we reached the place, past noon, students were leaving. At the door I found the principal who knew me and kindly invited me to tour the facility. The modern infrastructure coincides with what I read and saw in pictures and on television. In the administrative offices there were still boxes to unpack. Several facilities such as the lunch room and computer lab were still dismantled. In one of the three classrooms we visited, the principal asked a teacher to tell me how the digital whiteboard worked; I also asked her to explain how she used it in class. After a few minutes it was evident that the teacher did not know how to use it. Training had not arrived yet. Meanwhile teachers were still using conventional whiteboards. As for computers, they had been removed a few days after the opening because they were not ready to use. In addition, thieves had broken into the school and taken some equipment, making clear the vulnerability of the building. All these problems are repeated in other SOMs of the country: security issues, maintenance, underutilization, training, pedagogy. In terms of infrastructure, this is a palace compared to public and private schools in the country, and to the students' houses, probably very humble. Infrastructure, by itself, 
does not change pedagogy. Technology, if it is not appropriately exploited, it just becomes a useless ornament (Torres, 2012).

\subsection{Ecuadorian Education Entering the Rankings}

Unfortunately, the new education system has become another quantitative reform that is more interested in the numbers, statistics, and rankings than in the essential factors of the teaching-learning process and in the wellbeing of the ones who teach and the ones who learn. In fact, on December 4, 2014 the government proudly announced the results of the Regional Comparative Study (Terce), carried out by the Education Quality and Evaluation Latin American Lab (LLece) from UNESCO, which show a significant improvement in the country's education system (Ministerio de Educacion del Ecuador, 2014). Additionally, Ecuador will participate, for the first time, in the Program for International Student Assessment (PISA) as part of the pilot program designed by the OECD for developing countries (PISA for development). Nevertheless, it has been seen all over the world that results of standardized evaluations do not represent the reality of education systems. Regrettably, the main objective when taking these tests is to pass them and get a good ranking position instead of teaching quality and students' learning. Giroux (2009) argues that standardized testing deskills teachers because it weakens their critical pedagogical inquiry and reduces their practice to teaching to the test.

Although the government has increased public investment in education - new buildings, latest technology, recently edited textbooks and resources - almost no attention has been given to the initial and continuous training of teachers. It seems that the order in which the ruptures (objectives) were grouped and presented is also the order of the government's priorities, leaving the revalorization of the teaching profession as the last rung on the ladder. Teachers should be looked after first as they are the main component of high-quality education. This is precisely the truth behind the "big lies"; the asymmetries between the sacred stories of the government and the realities of teachers.

There is a sense of powerlessness among teachers because they have been labeled as lazy, unprepared and unprofessional. Older teachers have been segregated and even forced to retire due to their age and lack of official degrees; their accumulated knowledge and experience have not been recognized as valuable foundations; instead, they have been found guilty of failed education processes.

The government claims to be progressive and in favour of liberal ideologies that fight against imposing and absolutist systems; nevertheless, the country's leader has a populist vision that eliminates people as thoughtful individuals making them believe that everything can be solved only with his intervention. Teachers have been subordinated and made invisible; they have been given the passive role of receptors and trainees. They are considered mere transmitters of prescribed curricula with no opportunities for using autonomous and critical pedagogical practices.

More opportunities have opened up for young people to enter the teaching career not as a way to renew or revitalize the profession but as a way to save money; the salary that was paid to a thirty-year permanent teacher that 'voluntarily' retired is now used to pay two or three young, unexperienced, temporal novice teachers. Chomsky (2014) compares this practice to a business model in which the intention is to keep the costs of labor low, making sure that workers are submissive and compliant because they fear layoffs. "If workers are more insecure, that's very 'healthy' for the society, because if workers are insecure they won't ask for wages, they won't go on strike, they won't call for benefits; they'll serve the masters gladly and passively. And that's optimal for corporations' economic health" (Chomsky, 2014). Even though Chomsky is talking about this situation as a phenomenon now seen at higher education institutions, his explanation can be easily used to analyze what is happening in Ecuador at all levels of education in the public - where the government is the 'corporation' saving money - and in the private systems. Chomsky also mentions the ways in which teachers are being controlled: large classes, work overload, lack of opportunities to advance in the career ladder, and fear to look for another job because there are no other options - all "techniques of discipline, indoctrination, and control" (2014) seen in a 'pseudo-liberal' Ecuador whose educational reform is disempowering its teachers.

\section{Teachers in Ecuador}

I will continue with an analysis of the current situation of Ecuadorian teachers within the literature of teacher empowerment to better illustrate my arguments about the inconsistencies that exist between the written objectives and the real condition of the teaching practice.

Teacher empowerment has been defined by different scholars (Short, 1992; Irwin, 1990; Klecker \& Loadman, 1996); these definitions present recurrent themes that summarize teacher empowerment as a process whereby teachers 
develop autonomy, problem solving skills, and responsibility. Empowered teachers are able to pursue personal and professional growth, make decisions, and control situations (as cited in Duhon, 1994).

Duffy (1994) argues that teacher empowerment will be only achieved if teachers understand that their job is more than following dictates of administrators and textbook writers; it is developing a thoughtful and critical community of teachers who need to provide endless literacy and critical thinking opportunities to their students.

Three different theoretical views about the importance of teacher empowerment were identified by Duhon (1994). First, the teacher professionalism view argues that teachers are the ones who should assess the needs of their students due to their knowledge of instruction and curriculum; second, the bureaucratic centralization view which considers that more empowerment equals less effective teaching and lower achievement because teachers start to worry about decisions to be taken by administrators and designers and abandon their daily obligations; and third, the loose coupling perspective that presents schools as "loosely coupled" sites in which decisions made by teachers do not have any impact on their practice or the system. The second and third views argued by Duhon (1994) are contradictory to the first one and in fact they cancel it completely which suggest that achieving teacher empowerment per se might become a utopia if teachers' stories are kept secret and covered.

As it was previously mentioned, the Ecuadorian government has had the intention to revalorize the teaching profession through four objectives. Restructuring the teaching career and helping the teacher become a professional is the first objective of the MOE. Nonetheless, the actual conditions of educators have not been considered in the restructuring plan. Teachers have been prevented - again - from expressing what their motivations, interests, and inquiries are; their previous knowledge and available time and resources have not been evaluated. They have been ordered to enroll in a training program which is homogenous and does not adjust to different types of teachers and their specific needs. The program is not coherent with the pedagogical model proposed for teachers to practice in the classroom. While teachers are encouraged to use active teaching pedagogies such as participation, creativity, and critical thinking, their training program is teacher centered and heavily academic and theoretical.

The second and third objective are closely related because they refer to choosing the best and brightest in order to achieve excellence in teachers. Selection is done through competitions and salaries are based in meritocratic scales. Since there are not yet high-quality teachers, according to the MOE officials, because they are in training process, there have not been many competitions lately and most of the current positions are temporary. Temporary employees are not included in the meritocracy scale thus their salaries are lower.

In March, 2014, the National University of Education (UNAE) - the fourth objective of the MOE - was inaugurated. It was created with the purpose of contributing to the training of teachers and other professionals in the education field. This public university - another palace as the SOMs aforementioned - opened its doors in with 28 students (the building has a capacity for 3600 people). Although the number increased to 639 students in February 2016, it is easy to realize that there is either lack of interest in becoming a teacher or there are still many doubts among people about the reasons behind the creation of this university. An important antecedent to clarify this last point is that prior to the establishment of this new institution, all Normal Schools of the country were closed, alleging poor quality of education - teachers' educators of these institutions had to 'retire' and others were relocated in elementary or high schools. In addition, all education programs of private and public universities will be cancelled gradually and UNAE will be the only teaching training institution in the country. Thus it is rather plausible to doubt about the type and quality of training that students will receive at UNAE if there are no other options to choose from. What is worrisome is whether UNAE students will be prepared to be critical thinkers, autonomous professionals, problem solvers, and powerful agents of a profound and systemic education change, or indoctrinated individuals that will repeat political discourses in the name of the educational reform. Giroux (2010) argues that universities or colleges of education that follow a particular political view are created as places that could "dumb down teachers."

My argument is organized around the assumption that at the heart of such reform is an attempt to create colleges of education that will largely train teachers rather than give them a rigorous critical education. The dire effects of the reform measures will include turning colleges of education and alternative routes to certification into gatekeepers for a new kind of pedagogical culture and learning environment in which teachers are dumbed down. If left to proceed unchecked, reform will mean the advancement of a formative pedagogical culture that promotes political and cultural illiteracy while making teachers and students more receptive to the disempowering disciplinary practices of neoliberal policies, values, and social relations (Giroux, 2010, p. 345)

It may seem contradictory to support my arguments with literature that refers to neoliberalism when analyzing an education system that is part of a progressive, post-neoliberal government. Although there is an important increase in 
social spending, the stronger presence of the State, promoted by government, does not necessarily oppose the neoliberal model. There is a struggle within the State because while there is a nationalist and welfare policy that breaks with neoliberal ideologies, there is a modernizing economy project that demands the centralization of political power. In the words of Herrera (2014), "although more State presence both in political and economic terms favors a greater regulation of the economy in Ecuador, the State is not opposed to neoliberalism because the government not only neutralizes social or popular organization, but also moves towards global capitalism where neoliberalism remains."

\subsection{Disempowered Teachers}

Sprague (1992) identifies problems of capitalism and neoliberalism as factors that have led to the disempowerment of teachers: feminization, technologization, deskilling, intensification, and privatization.

Feminization refers to the presence of more women in the teaching profession, which according to Apple (1993) has made the evolution of the profession slower. In regards to this factor, it is necessary to recognize that the Ecuadorian education system acknowledges gender equality and requires schools to hire more male teachers - as historically more women have chosen to become teachers. Additionally, if the school principal is a man, the vice principal has to be a women or vice versa.

Technologization and deskilling go hand by hand as they contribute to make teachers lose control over their practice because they are asked to follow prescribed curricula and use textbooks that many times do not meet students' specific interests or needs. Again the problem lies in that teachers are not included when making decisions about what to include in programs and resources. Giroux and McLaren (1986) argue that curriculum "is designed to be applied to any classroom context regardless of the historical, cultural and socioeconomic differences that characterize various schools and students" (as cited in Sprague, 1992, p. 186). Regrettably this situation is present in the Ecuadorian education system. One curriculum one program, one set of textbooks that respond and match the government'political agenda; in other words a one size fits all approach that has failed so many times in different parts of the world. Moreover, the contents have increased in number and depth that teachers have to rush to finish the plan with no possibility to address students' individual difficulties.

To better explain intensification and its significance in teaching in Ecuador, I would like to include an excerpt from an interview I had with a high school teacher with more than 25 years of experience. To protect confidentiality and privacy names will not be mentioned.

Excessive work in extra-curricular activities - paper work, teaching dossiers, daily written planning outside the classroom are making us feel burned-out. We teach 30 to 40 hours a week and as a result we are declining our teaching quality. Teachers are responsible for a high number of students and in these circumstances it is very difficult to meet the objectives proposed by current regulations. The little responsibility of parents regarding the education of their children add more work; parents have given teachers and educational institutions the entire obligation to care and educate their children.

The place in which teachers are located within the current education system has pushed them somehow to become isolated and private, and to lose the sense of unity among colleagues. Since the severe problems between the National Teachers Union (UNE) and the government in 2009, teachers do not want to form groups because they fear the consequences - the president of UNE was convicted of 'terrorist crimes' for protesting against the system. It seems the government has accomplished its purpose "keeping teachers separated so that they cannot discover the common causes of their oppression and unite with other workers to resist" (Sprague, 1992, p. 188).

\section{Can Ecuadorian Teachers Regain Power?}

The government has devalued and discouraged the teachers practice. It has not acknowledged that the teachers' job is to harvest the most difficult crops: intelligence and emotion. It is imperative for teachers to make their voices heard and to demand the position they deserve as they are the indispensable component of any education system. It is necessary to show the government the power teachers hold within by questioning rules and challenging systems. It is necessary to convince the government that the main objective when trying to revalorize the teaching profession should be to increase teachers' power, "to accept their participation in the determination of goals and policies, and to exercise professional judgement about what to teach" (Bolin as cited in Sprague, 1992, p.189).

It is necessary to recognize that this government has undertaken an educational change that past governments did not dare or care to start. It is also necessary to agree that to achieve a 'citizen revolution' it is necessary to have an 'educational revolution,' but to succeed in this profound transformation, it is imperative to encourage and support a 
'teaching revolution' which will only be possible by creating the necessary conditions to make the teaching profession an attractive and stimulating career option for young people. Teachers should feel encouraged to make the most of the opportunities that exist. The set objectives could be better accomplished if teachers commit to their daily preparation by acquiring and transforming knowledge which in today's society equals to development and power.

\section{Conclusion}

The public discourse about education is focused on how much money is invested in building hundreds Schools of the Millennium, in buying the latest technology, and in renovating buildings. Nonetheless, the real change or 'revolution' lies in the importance given to the human resources that are part of the educational process. Proper initial training and continuing professional development of teachers, and education of students to become agents of change in Ecuador should be the most important aims of the education system. A transformation is not a result of a decree or higher investments, and does not happen overnight. An integral education policy is one that is systemic and holistic. It includes structural conditions such as the training of teachers and the quality of learning, and conjunctural aspects with the tools to meet those conditions.

Education administrators in Ecuador ought to understand that the most important allies to achieve the desired transformation are the teachers. They should be given the right to participate in decision-making processes to propose changes that address their and their students' real needs. Ecuadorian teachers living this crucial moment in the history of education should be given the opportunity to grow as leaders and to become empowered individuals who will commit to the success of a real educational revolution.

\section{References}

Apple, M. (1993). the Politics of Official Knowledge. Teachers College Record, 222-241.

Chomsky, N. (2014). How Higher Education Ought to be on Academic Labor. (R. Clarke, A. Davis, D. Hoinski, M. Somma, R. Sowards, M. Ussia, \& J. Zalesnick, Interviewers) Pittsburgh, PA. Retrieved from http://www.counterpunch.org/2014/02/28/on-academic-labor/27/

Clandinin, D., \& Conelly, F. (1996). Teachers' Professional Knowledge Landscapes: Teacher Stories-Stories of Teachers-School Stories - Stories of Schools. Educational Researcher, 25(3), 24-30..

Duffy, G. (1994). Professional Development Schools and the Disempowerment of Teachers and Professors. The Phi Delta Kappa, 75(8), 596-600.

Duhon, G. M. (1994). Teacher empowerment: Definitions, implementations, and strategies for personal renewal. Retrieved from http://search.proquest.com/docview/62393197?accountid=14771

Giroux, H. (2009). Teachers as transformative intellectuals. In K. Ryan, \& C. J., Kaleidoscope: Contemporary and Classic Readings in Education (pp. 35-40). Cengage Learning.

Giroux, H. (2010). Dumbing Down Teachers: Rethinking the Crisis of Public Education and the Demise of the Social State. The Review of Education, Pedagogy, and Cultural Studies, 32(4-5), 339-381. http://dx.doi.org/10.1080/10714413.2010.510346

Herrera, L. (2014). Estado y neoliberalismo en el Ecuador: algunas contradicciones no resueltas. Plan V. Retrieved from

http://www.planv.com.ec/ideas/ideas/estado-y-neoliberalismo-el-ecuador-algunas-contradicciones-no-resueltas

Ministerio de Educación del Ecuador. (2012). Educación para la Democracia y el Buen Vivir. Retrieved from Ministerio de Educación: http://educacion.gob.ec/educacion-para-la-democracia-y-el-buen-vivir/

Ministerio de Educacion del Ecuador. (2014). Ecuador mejoro su sistema educativo en los ultimos 7 años. Retrieved from Ministerio de Educacion: http://educacion.gob.ec/ecuador-mejoro-su-sistema-educativo-en-los-ultimos-7-anos/

Ramirez, R. (2008). Igualmente pobres, desigualmente ricos. Quito: Editorial Ariel, Programa de Naciones Unidas para el Desarrollo.

Ramírez, R. (2013). Tercera Ola de Transformación de la Educación Superior en el Ecuador. 2013: Senescyt.

Sprague, J. (1992). Critical Perspectives on Teacher Empowerment. Communication Education, 41(2), 181-203. http://dx.doi.org/10.1080/03634529209378879 
Torres, R. M. (2012). Proyecto arquitectónico sin proyecto pedagógico. Retrieved from Otra Educación: http://otra-educacion.blogspot.ca/2012/01/proyecto-arquitectonico-versus-proyecto.html

Van Damme, W., Aguerrondo, I., Crespo Burgos, C., \& Robalino Campos, M. (2013). A Story of Change: How Ecuador Seeks to Sustain its Development Agenda through Large Scale Education Reform. UKFIET International Conference on Education and Development - Education and Development post 2015: Reflecting, Reviewing, Re-visioning., (p. 15). Oxford. 